\title{
A Case Study: The Use of Songs to Enhance Year 1 Pupils' Vocabulary
}

\author{
Hasfiyah binti Assan ${ }^{[1]}$, Hamidah binti Yamat ${ }^{[2]}$ \\ ${ }^{1}$ SK Abang Kadir Gedong, D/A PPD Simunjan, 94800 Simunjan, Sarawak \\ ${ }^{3}$ Faculty of Education, Universiti Kebangsaan Malaysia (UKM), 43600 Bangi, Selangor, Malaysia \\ DOI: $10.29322 /$ IJSRP.10.02.2020.p9815 \\ http://dx.doi.org/10.29322/IJSRP.10.02.2020.p9815
}

\begin{abstract}
Teaching English as a second language to primary school pupils is not easy. This study aims to investigate whether Year 1 pupils exposed to the use of English songs in the class would experience a change in vocabulary competence. To fulfil this purpose, 24 Year 1 samples were selected from a primary school located in Simunjan, Sarawak. The participants were examined through a pretest, post-test and semi-structured interviews. The pre-test and post-test were designed and developed according to the songs which had been chosen to teach the target vocabulary by the researcher. Data was gathered through documents and interviews. Results showed that the pupils experienced an improvement in their vocabulary. Using English songs to improve the vocabulary among Year 1 pupils is indeed an interesting and effective method. Proper implementation and song selections would contribute to pupils improvement in acquiring new vocabulary effectively.
\end{abstract}

Index Terms- English songs, vocabulary, improve

\section{INTRODUCTION}

$\mathbf{I}^{\mathrm{n}}$ Malaysia, English language becomes the second language that has a vital role to the development of the country. The use of the language has been introduced to all level of education in Malaysia. Mastering English language is an important value for students to have. Teaching English especially to pupils is indeed a challenging task to do. Pupils sometimes face some difficulties in acquiring English as their second language. It is clearly emphasized in the Malaysia Education Blueprint (2013 - 2025) that vocabulary is one of the crucial aspects to be developed among learners. Therefore, teachers should be creative in selecting pedagogical tool in teaching English for their pupils.

Vocabulary is the basic unit of a language. According to Ika Devi (2019), the basic of vocabulary is emphasized in primary school. Through the mastery of vocabulary, pupils will be able to communicate and convey their messages effectively. This can also be supported by Schmitt (2008) by saying vocabulary is an important component in language mastery. However, many pupils face difficulties when they communicate in English due to lack of English vocabulary especially when it involves complicated words. Pupils could not comprehend the meaning of words due to their limited mastery of vocabulary. This issue can be supported by Alqahtani (2015) which stated that some researchers have shown that second language learners rely heavily on vocabulary knowledge and it is the largest obstacle for learners to overcome. Having limited vocabulary is a barrier that prevents pupils from learning the language. With a wide range of vocabulary, pupils will be able to express their opinions or thoughts conveniently. Low vocabulary mastery will make pupils unable to express their communicative in English.

Teaching English in primary school aims to encourage pupils to be confident in using the language in their daily communication. Language is an important tool for people to communicate or interact with one another. Richards and Schmidt (2011), stated that people use language to give and receive information and exchange ideas among them. In education context, language is used to develop pupils' communicative competence in speaking form. Moreover, in Common European Framework of Reference (CEFR) lesson in Level 1, it is clearly highlighted that the vocabulary are introduced in each topic with songs.

\section{LITERATURE REVIEW}

The use of English songs in the teaching and learning process have been experimented and used by researchers from various levels to improve pupils' vocabulary. The vast majority of pupils do not have the opportunity to interact in English due to several limitations such as their environments at home and school which lead to the language is not meaningful. This study was carried out to find out the effects of using English songs in improving pupils' vocabulary by incorporating musical intelligence. In mastering a language, it is 
crucial for the learner to acquire the vocabulary. It is known that vocabulary is vital in learning of language particularly of a second language as in our country.

In acquiring vocabulary, there are numerous strategies have been introduced in order to master the target language. The use of English songs has been used in various level education namely primary schools, secondary schools and tertiary education. Teachers have an immense role in ensuring the pupils could enrich their vocabulary through the strategies applied in the classroom. The selection of words to be introduced in every lesson is crucial in teaching and learning vocabulary. This statement is supported by Kurniawan (2009) which said that words chosen should be advantageous for students. This means, the input needs to convey meaning and be comprehensible so that those words will be meaningful to the pupils.

It has been proved that the use of English songs is indeed effective in improving pupils' vocabulary based on several past researches which can be related to this study. A study by Ika Devi (2019) on the implementation of English songs to increase first grade pupils' vocabulary has shown that it is a stress-free activity which left positive impact on the pupils as they could memorize vocabulary due to the nature of songs. Songs consisted special rhythm that stimulates brain to catch the lyrics. Therefore, pupils could learn new vocabulary through the integration of songs in the lesson. Based on the study carried out by the researcher, the selection of songs is very important to ensure words in the lyrics are appropriate for the level of pupils.

Teachers' views on the use of English songs is important as well as teachers are the ones who will apply the strategy on their pupils. A local survey study was carried out by Tse (2015) on Malaysian Teacher's Perspectives on Using Songs in Language Teaching. The result depicted that Malaysian teachers had difficulties in selecting songs. However, songs can become useful sources to assist language learning and acquisition if teachers possess the strategies in using them. The findings from this study revealed that teachers agreed on the potential of using songs in teaching ESL to young children.

In short, the use of English songs is one of the strategies in improving pupils' vocabulary by mean pupils could comprehend the words they have learned in the lesson. Various studies have been carried out in the past showed that, there are potentials of using songs in teaching English as a second language.

\section{Research Design}

\section{RESEARCH METHODOLOGY}

The research design is a quantitative study which utilized the case study approach. A case study research design is a process or record of research into the development of a particular situation over a period of time.

\section{Sampling}

The participants of this study were selected through purposive sampling in which several criteria were taken into accounts before conducting the study. Creswell (2014) stated that, when individuals are not randomly assigned, the procedure is called quasiexperiment. These participants were taken from one class which was Year 1A. According to Cavana et al. (2001) as cited by Creswell (2008), purposive sampling is used to obtain valid data from the respondents or representative sample and to avoid from a biased sample.

Firstly, all participants were of the same age which was seven years old. Secondly, participants from the class had similar level of proficiency in English. These two criteria were being considered in selecting the sampling for this study. All of the participants are experienced a pre-test and post-test.

\section{Research Instruments}

There are two main instruments used in the study namely pre and post-test and semi-structured interviews.

\section{A) Semi-structured interviews}

Interviews was conducted as well in which simple questions were asked to the participants after the lesson. The questions were asked in the classroom especially towards the end of every lesson in which English songs were used. Through this interview, pupils' perception on the use of song can be assessed by categorising the feedback given by pupils.

In this study, the researcher adopted simple questionnaires which was to validate the entire study. 


\section{B) Pre and post-test}

Students are given the pre-test by the teacher before the introduction of the unit to identify and determine their vocabulary knowledge. They are given 30 minutes to complete the pre-test.

The students undergo a post-test given by the teacher before the teacher finishes the unit. As in the pre-test, the students are given 30 minutes to complete the post-test.

\section{DATA ANALYSIS}

Central tendency of descriptive statistics is selected to analyse the data of pre and post marks using Statistical Package of Social Sciences (SPSS).

Table 1: Data Analysis

\begin{tabular}{|c|c|c|}
\hline Pupil & Pre-Test & Post-Test \\
\hline A & & \\
B & 8 & 19 \\
C & 2 & 14 \\
D & 6 & 14 \\
E & 19 & 27 \\
F & 15 & 25 \\
G & 3 & 12 \\
H & 17 & 26 \\
I & 20 & 27 \\
J & 11 & 27 \\
K & 14 & 20 \\
L & 5 & 10 \\
M & 9 & 23 \\
N & 2 & 22 \\
O & 19 & 27 \\
P & 10 & 21 \\
Q & 11 & 23 \\
R & 11 & 20 \\
S & 4 & 13 \\
T & 20 & 27 \\
U & 12 & 20 \\
V & 9 & 18 \\
W & 3 & 17 \\
X & 16 & 26 \\
& 13 & 23 \\
Mean (M) & & \\
\hline Standard Deviation (SD) & 5.89 & 20.87 \\
\hline & & 5.34 \\
\hline
\end{tabular}

Using Statistical Package of Social Sciences (SPSS), the following are the results of this analysis; pre-test, $\mathrm{N}=24, \mathrm{M}=10.79, \mathrm{SD}=5.89$ and post-test, $\mathrm{N}=24, \mathrm{M}=20.87, \mathrm{SD}=5.34$. The results show that the pupils' scores are more consistent and higher during post-test.

Apart from administering the pre-test and post-test, semi-structured interview sessions were carried out to determine the perceptions on the use of English songs as a pedagogical tool to improve their vocabulary. 


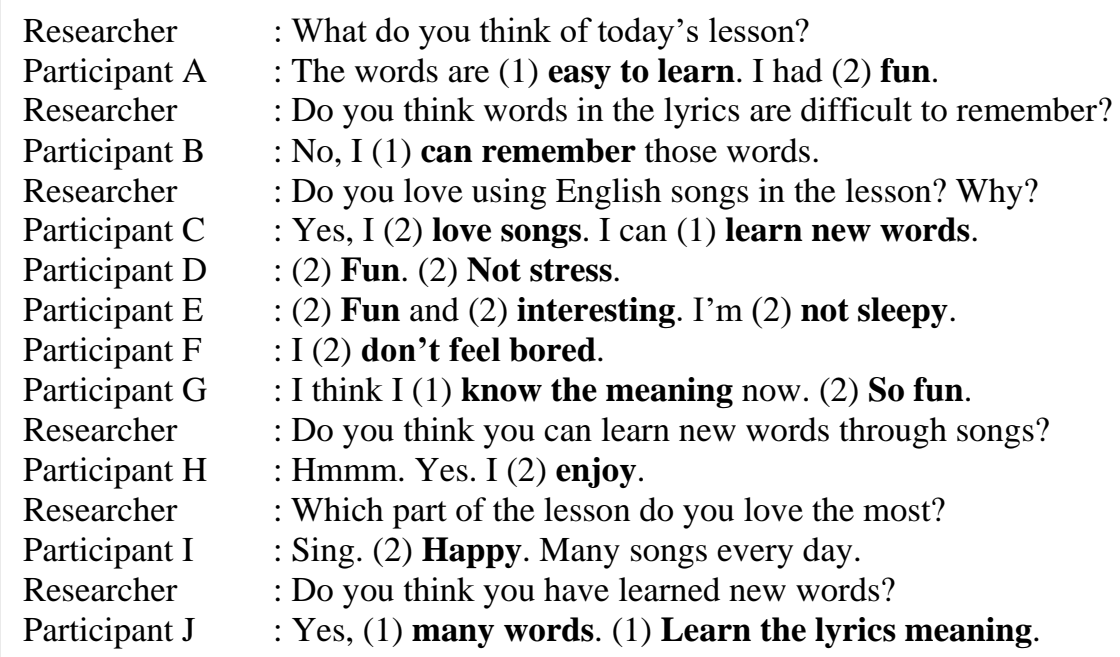

\section{IMPLICATIONS}

\section{Teachers}

This research would help teachers to integrate the use of songs in the lessons as a pedagogical tool. Thus, the use of songs would help teachers to conduct a fun lesson as pupils would be able to participate actively.

\section{Pupils}

Pupils' level of motivation to acquire English vocabulary would incline as the use of songs in the lesson could help to minimise their anxiety level. These two aspects are crucial in order to ensure a language could be acquired effectively. Furthermore, based on the Theory of Multiple Intelligences proposed by Gardner (1983), a pupil's full range of abilities and talents could be captured with the integration of songs in the lessons. Pupils with high motivation in learning the language can excel in mastering the language.

\section{School}

This study would help in contributing ideas on methods to be used to improve pupils' vocabulary. Apart from that, using songs with pupils gives teachers more opportunity and time for realistic classroom teaching, and allows better and much varied opportunities for the pupils to practice the new vocabulary. This positive and promising perception towards the use of English songs as a tool to improve pupils' vocabulary could be used as a moral boost in order to create a more positive and cheerful teaching and learning in language classroom.

\section{SUMMARY}

The use of English songs among pupils would be effective if the lesson is properly planned. Indeed, there are several factors which affect to the effectiveness of such learning processes. As a matter of fact, the findings of this study has showed positive effects not only on pupils' vocabulary but their participations, behaviours and interests as compared to the control group. The experimental group had far more significant improvement than the control group who went through the conventional way of teaching.

In a nutshell, using English songs to improve the vocabulary among Year 1 pupils is indeed, interesting and effective method. Proper implementation and song selections would contribute to pupils' improvement in acquiring new vocabulary effectively.

to improvise the maximum. 


\section{REFERENCES}

[1] Ika Devi. (2019). The Use of Songs to Increase English Vocabulary to the First Grade Students of Sdn Tugu Jebres No.120. Sukarta: Universitas Sebelas Maret.

[2] Gardner, H. (1983). Frames of Mind: The Theory of Multiple Intelligences.

[3] Creswell, J. W. (2008). Educational research: Planning, Conducting, and Evaluating Qquantitative and Qualitative Research (3rd ed.). Upper Saddle River, NJ: Pearson Education, Inc.

[4] Alqahtani, M. (2015). The Importance of Vocabulary in Language Learning and How to Be Taught. International Journal of Teaching and Education, III, 21-34. No.3

[5] Schmitt, N. (2008). Instructed Second Language Vocabulary Learning. Language Teaching Research, 12(3), 329 - 363. Cambridge: Cambridge University Press.

[6] Kurniawan, E. H. (2019). Improving Vocabulary Ability by Using Comic. Cendekia, 1-8.

[7] Tse, A. Y. H. (2015). Malaysian Teachers' Perspectives on Using Songs in English Language Teaching. International Journal of Social Science and Humanity 5:1. Pp. 87-89.

\section{AUTHORS}

First Author - Hasfiyah binti Assan, Master's Student (TESL), SK Abang Kadir Gedong, Faculty of Education, Universiti Kebangsaan Malaysia, hasfiyahassan290493@ gmail.com.

Second Author - Hamidah binti Yamat, Faculty of Education, Universiti Kebangsaan Malaysia, hamidah_yamat@ukm.edu.my. 